\title{
Financial Statement Analysis in Municipalities and an Application
}

\author{
Ali Kablan ${ }^{\mathrm{a}}$, \\ ${ }^{a}$ Assistant Professor, İstanbul University, Departmant of Accounting and Financial Management, İstanbul, Turkey
}

\begin{abstract}
In order to meet increased demand for services, municipalities are compelled to use their resources in a most efficient manner. The regular collection of revenues in municipalities, while making expenditures in most efficient ways depend on the healthy functioning of the budget and accounting and the financial control system correspondingly. In is necessary for municipalities to continuously control the balance of incomes and expenses, determining and eliminating the negativities in this balance. For this purpose, financial analyses and management ratios are needed. With the financial analyses made, a financial control system may be established in a municipality and used for management purposes. The importance of this study is that if the organizations and enterprises belonging to the public can apply the analysis techniques as profoundly as the private sector organizations and enterprises, those municipalities which continuously produce information through financial control can take corrective actions in line with such information, and by determining out of which items the increases and decreases in revenues and expenses arise they will take actions in order to decrease expenses and to increase revenues. In addition, it will be possible to apply financial carnets (ration cards) to public organizations and enterprises. For this purpose, sorts of financial analyses are mentioned in the study, and an application is included in the municipality of Beylikdüzü for analyzing financial tables in public organizations and enterprises which are obtained as a result of accruals accounting. In the application, the Balance Sheet and Table of the Operating Results for the year 2012 are subjected to comparative statements, and to percentage and ratio analyses; and then the results are interpreted.
\end{abstract}

Keywords : Financial Statements, Horizontal Analysis, Vertical Analysis, Ratio Analysis, Public Sector

\section{(C) 2013 Published by SSBFNET}

\section{Introduction}

The word 'belediye' (municipality) which in terms of its roots is an Arabic word was derived from the work 'belde' (town) which means the place inhabited by a community of people for settlement purposes. Therefore municipality means establishment and management related to township (Nadaroğlu, 2001, p:197). The notion of municipality in Article 3 of the Municipality Law no. 5393 expresses "a public legal entity, holding administrative and financial autonomy, established for meeting the inhabitants of a township common local needs and formed through the election by electors being the decision making body".

As known, the traditional understanding of public administration foresees that everything in the use of authority is transferred from the top to the bottom under the control of a central administration. The modern understanding of public administration however accepts that the functioning of the system with the "subsidiarity principle" is reversed and the actual holders of authority are in fact sub-local units. Due to these differences of opinion, the distribution of duties and authorities between authorities in the provision of public services and a change in the ordering thereof has been necessary. Thereby, works for the widespread distribution of authorities by the transfer of part of authorities, sources, duties and functions held by the central administration primarily to local administrations and rural entities, voluntary organizations and civil society have accelerated (Ferlie, 1997, p:15).

The daily recording and keeping of all financial data to be needed by the public sector in an accurate and reliable manner; the processing and analysis thereof and the timely submission of the administrative information and financial

\footnotetext{
${ }^{a}$ Corresponding author.
} 
information produced thereby to managers holding decision making positions are of vital importance for a healthy fiscal management. A well designed management information system produces accurate, reliable, timely and sufficient information as well as the required reports for administrators in decision making processes. Thereby, while assisting the administrators in taking efficient, timely and accurate decisions, it plays an indispensable role in their performance of accountability responsibilities (Karaaslan, 2004, p:37).

In countries where the accrual based accounting system is not practices, information other than the central administration of the accounting information systems implemented in municipalities cannot be produced. The accounting system provides information as to whether money is used within legal frameworks and does not produce information which can be used by the administration for planning, execution, control and success assessment. With the start of use by many countries across the world of accrual based accounting system, the use of resources has come to be fully trackable by accounting, while balance sheets, activity outcome tables, cash flow tables and similar tables of the municipalities have come to be provided to the information of the public. With the reporting system in municipalities by this structure; obtaining information of the sources of the institution and the use thereof, the financing method of the institution and the display of how cash need is met, the ability to see the capacity of the institution to finance its activities and fulfill its responsibilities and commitments and ensuring information for the assessment of the efficiency and success of the financial standing has become possible (Türkyener, 2011, p: 47-58).

Fiscal administration philosophy in Turkey has fundamentally changed with Public Finance Management and Control Law no. 5018 which may be characterized as the constitution of the fiscal system which started to be applied as of 01.01.2006 in our country. The most important novelty brought by the said Law is the alteration of the public accounting system and the transition to an accrual based accounting practice in public accounting. In order to ensure auditing in the procurement and use of all kinds of public sources in Article 7 of the said Law, titled "Financial Transparency", the provision stipulates that the public shall be informed on time and that for this purpose public accounts shall be formed by a standard accounting system and an accounting order in conformity with generally recognized accounting principles is mandatory (Erdoğan, 2007, p:24). In addition thereto, with the provision in Article 49. regulated by the accounting system stating that, "An accounting system is established and executed as to ensure the effective decision-making, control and accounting processes and underlies the draw-up of financial reports and final accounts. Public accounts are kept to establish public administrations in conformity with commonly accepted accounting principles for incomes and expenditures, the registry of all guarantees and obligations within a determined order by all procedures causing the increase or decrease of equities and bearing financial outcomes by its assets and providing the public with necessary information by management and auditing officials", emphasis has been placed on control and accountability, while the accrual based accounting system has been described and the implementation of this system has been regulated.

Accountability however is defined in Article 8 of Law no. 5018. By this Article, those who are assigned and authorized for the obtainment and use of all public sources are held responsible for the efficient, economic, productive and legal obtainment, use, recognition, reporting of resources and taking necessary precautions for preventing the misuse thereof. Various sanctions have been foreseen for those who fail to fulfill said responsibilities. With Law no. 5018 , accountability has been condition on the reporting activity, while those holding accountable positions have been obliged to inform the public with regular intervals (Alkış, 2011, p:20)

The accrual based state accounting system has not only brought by an order registering all incidences by public institutions bearing economic consequences, it has also made it obligatory to produce financial statements ensuring the use of these information in the processes of decision-making and the assessment of activities. However, it is also necessary to analyze the financial statements for completing the assessment of institutions' financial standing and for resolving on the matter. The private sector has been using financial statement analysis techniques for a long time.

The objective of this study is to examine and see whether it is possible to apply the financial statements analysis techniques on the financial statements especially on balance sheets and operating results statements which are prepared in the public organizations and enterprises according to accruals accounting; and on the other hand, another objective of the study is to contribute to the usage of accruals accounting by decision makers more effectively as in the private sector accounting. In the study, firstly, the development of the financial statement analysis techniques are 
discussed, and in the sections of the study that follow, the financial statements of the municipality of Beylikdüzü for the year 2012 are subjected to comparative, percentage, and ratio analyses.

\section{Development Of Financial Statement Analysis}

The analysis of financial statements in the private sector had initially occurred in the 19th century in the US with the changes in the company structures. During this period, family owned enterprises came to be replaced by larger companies, which were in need of great financial resources. Larger companies which failed to meet their resource needs from their equities started to go into debt. In order to foresee whether the debt they've granted will be paid back, creditors have started to apply financial statement analysis methods to determine the financial standing of companies. In addition thereto, the emergence of conglomerates caused professional managers other than family members to assume roles in company management. Shareholders who left managerial position to professional managers also felt the need to measure the success of managers and this need caused the emergence of financial statement analysis methods (Horrigan, 1968, p:284-285). During the first implementations, assets were classified as current assets and fixed assets, while the "current ratio" emerged with the comparison of current assets and short term liabilities in the 1880s (Horrigan, 1968, p:285). With Wall's study, profitability margins came to be used for the first time in analysis. Another significant development in this period however the development of the percentage method and analysis method by Lawrance Chamberlain in his book titled "The Principles of Bond Investment". In the following years, the sector ratios and Trend Analysis method came to be used in the analyses (Wall, 1919, p:229-243). As a result, although its first implementations were very simple, financial statements analysis methods developed in course of time are nowadays used commonly by users of financial statements in order to determine companies' financial standing in decision making processes and make forecasts into the future.

\section{Analysis of Financial Statement in the Public Sector}

Although the analysis techniques for financial statements have a deep rooted past for the private sector and the presence of many studies conducted on this matter, studies in the analysis of financial statements for public institutions has started rather belatedly due to the public sector. The most important reason for this delay is that the purposes of public institutions are different from those of private sector companies. While the purpose of companies in the private sector is the maximization of profits, the purpose of public institutions is to provide effective, productive and economic resources and services for society. Activities for meeting common local needs ranks foremost among the reasons why the public institutions of municipalities are established (Başaran, 2008, p:30). Since administrative activities are undertaken for serving the public interest, the success or failure of these activities cannot be determined by the profitability criterion based on numerical calculations as in private sector enterprises. The purpose of a public institution is to serve the public interest, while the purpose of an enterprises increase its profits and maximize the company values. Therefore, profit cannot be used as a criterion for determining the success of a public institution's management (Eren, 2009, p:3). Not only public entities within general administration, but also public institutions established by commercial principles and acting according to special provisions at the same time place the public interest above the maximization of profits. Moreover, since public institutions have assumed different duties and are structured in different ways, it wasn't possible to suggest analysis techniques applicable for all public institutions. For these reasons, it wasn't possible to transfer and implement the analysis techniques based on profitability and developed for the private sector to and in the public sector. It is possible to state as a second reason that there is no demand in society for the analysis of public institutions' financial standings. Society and parliaments have not been very much interested in the financial standing of public institutions. As mentioned before, these studies have started with the request of shareholders and financiers using financial statements in the private sectors for analysis techniques, whereafter analysis techniques developed. However, since no similar request was made by the users of financial statements in the public institutions, studies were not conducted on this matter. The fact that these would allow the assessment of their own activities alongside the lack of such a demand by society and their representatives, caused administrators in the public sector to conduct studies in this field. Another reason why methods for analyzing financial statements in the public sector has not developed however is that a cash basis accounting was being commonly used in most countries' public institutions. Recording needs due to the importance of the budget has occurred with the budget use and a cash basis accounting system has been used in the public sector during this historic development process.

\footnotetext{
1 A borough within the provincial boundaries of Istanbul in Turkey with a population of 218.120 people (www.beylikduzu.gov.tr/nufus.aspx)
} 
Since the scope of the cash basis accounting system was rather narrow and the financial statements generated within this system did not include comprehensive information, it hasn't been possible to develop analysis techniques for financial statements.

However, the recent increase in the importance attached to the notions of transparency and accountability especially in developed democracies caused an increase in the interest in the financial standing of and use of resources by public institutions. Therefore the accrual based accounting system displaying the financial activities and standings more thoroughly has become widespread in many countries and studies on the analysis of financial statements generated by this system has become possible. In recent years, studies on the development of analysis techniques for public institutions' financial statements have been made. The most important studies on this matter were made on local administrations. This is because local governments making part of their investments by loans obtained from money markets in the US, where private sector financial analysis methods has first come to be implemented, endured financial crises, went bankrupt and faces difficulties in paying back their debts. In particular during the 1970, municipalities of greater and significant metropolitan cities such as New York and Cleveland in the United States went through financial crises and these crises caused the risk for administrations to fail to pay back the debts they have obtained from the money market to arise. (Groves, Godsey and Shulman, 1981, p:5). One of the results of these crises however, is the occurrence of the request by creditors in markets ensuring financing for local governments to know of the administrations' financial standing. It has become important to specify the local governments' financial standing and solvency and in order to meet this need, studies in the analysis of financial statements has begun.

\section{Methodology}

It is the financial statement techniques, comparative statements analysis, percentage method analysis, ratio analysis, and trend analysis that are applied in enterprises. Some of the financial analysis techniques used in enterprises are possible to apply on the financial statements arranged by municipalities. With the help of the comparative statements analysis method, it is possible to compare the financial statements of organizations and enterprises for the years that follow each other, and according to the percentage method analysis the magnitude of the items in a financial statement can be determined, and enterprises with different sizes can be compared. Whereas, in the ratio method, the relations between the financial statement items can be determined. On the other hand, in the trend analysis method, the tendency of the items of a financial statement in a long period of time can be observed.

In the application realized in the municipality of Beylikdüzü, comparative statements analysis, percentage method analysis, and ratio analysis were employed, However, trend analysis was not utilized. The reason for this is that trend analysis requires a long time span. Another reason is that accruals accounting application is new both in our country and in many other countries. So, long enough time hasn't passed for a healthy trend analysis, there haven't been enough data.

\subsection{Implementation Of The Analysis According To The Comparative Statement Method In The Municipality Of Beylikdüzü}

The comparative analysis is the method of comparing financial statements for different periods. It is possible by this method to observe the changes in the institution's financial standing. Thereby, it is possible to examine the reasons for changes occurring in the accounts and make forecasts for the institution's future standing. In as much as it is possible by the comparative analysis method to compare financial statements for different periods, it is also possible to compare the financial statements of different institutions (Tenker and Akdoğan, 2010, p:224).

It also possible to implement the comparative analysis method for our country's public institutions. By this analysis method, it is possible to examine institutions' financial status by comparing their consecutive annual financial statement. Moreover, since public institutions generally fulfill duties peculiar to themselves, the practice of comparing financial statements with those of other public institutions may be the case for many institutions with same job definitions yet in different structures such as municipalities, special provincial administrations. As an example in the study, a horizontal analysis study on the Beylikdüzü Municipality's annual balance sheets of 2011 and 2012 is given below. The study includes the comparison of statement sections and its main grouping is made on an accounts basis. The below formula is used in the calculation of changes. 
Table 1 : Comparative financial statements of the Beylikdüzü Municipality

\begin{tabular}{|c|c|c|c|c|c|c|c|}
\hline \multicolumn{8}{|c|}{ BEYLİKDÜZÜ MUNICIPALITY } \\
\hline \multicolumn{2}{|l|}{ ACTIVES } & \multirow[b]{2}{*}{2012} & \multirow{2}{*}{$\begin{array}{c}\text { HORIZONAL } \\
\text { ANALYSIS } \\
\% \\
\text { CHANGE }\end{array}$} & \multicolumn{2}{|l|}{\begin{tabular}{|r} 
PASSIVES \\
\end{tabular}} & \multirow[b]{2}{*}{2012} & \multirow{2}{*}{$\begin{array}{c}\text { HORIZONAL } \\
\text { ANALYSIS } \\
\% \\
\text { CHANGE }\end{array}$} \\
\hline & 2011 & & & & 2011 & & \\
\hline I- CURRENT ASSETS & 49.702 .744 & 55.789 .780 & 12.25 & $\begin{array}{l}\text { III- SHORT TERM FOREIGN } \\
\text { RESOURCES }\end{array}$ & 91.142 .991 & 118.370 .158 & 29.87 \\
\hline \multirow[t]{2}{*}{10 LIQUID ASSETS } & 9.605 .143 & 7.056 .738 & -2.65 & $\begin{array}{l}\text { 30 SHORT TERM INTERNAL } \\
\text { LIABILITIES }\end{array}$ & 4.744 .840 & 4.809 .566 & 1.36 \\
\hline & & & & 32 ACTIVITY PAYABLES & 37.916 .260 & 60.772 .730 & 60.28 \\
\hline 12 ACTIVITY RECEIVABLES & 34.643 .217 & 43.232 .530 & 24.80 & 33 CONSIGNED FOREIGN RESOURCES & 9.271 .024 & 10.883 .338 & 17.39 \\
\hline 14 OTHER ECEIVABLES & 171.317 & 937.764 & 447.40 & 36 OTHER LIABILITIES PAYABLE & 39.210 .866 & 41.904 .522 & 6.87 \\
\hline 15 STOCKS & 1.247 .047 & 1.195 .943 & -4.01 & & & & \\
\hline 16 PREPAYMENTS & 172.922 & 0 & -100 & & & & \\
\hline \multirow[t]{2}{*}{19 OTHER LIQUID ASSETS } & 3.863.095 & 3.366 .803 & -12.85 & $\begin{array}{l}\text { IV- LONG TERM FOREIGN } \\
\text { RESOURCES }\end{array}$ & 4.860 .022 & 257.673 & -94.70 \\
\hline & & & & $\begin{array}{l}40 \text { LONG TERM INTERNAL FINANCIAL } \\
\text { LIABILITIES }\end{array}$ & 4.860 .022 & 257.673 & -94.70 \\
\hline II FIXED ASSETS & 137.152 .040 & 161.531 .555 & 17.77 & V- EQUITIES & 90.851 .771 & 98.693 .503 & 8.63 \\
\hline \multirow[t]{2}{*}{22 ACTIVITY RECEIVABLES } & 3.685 .089 & 3.202 .161 & -13.10 & 50 NET VALUE & 55.474 .423 & 66.980 .319 & 20.74 \\
\hline & & & & \begin{tabular}{|l} 
57 POSITIVE OPERATING RESULTS OF \\
THE PREVIOUS YEAR
\end{tabular} & 35.377 .347 & 31.713 .183 & -10.36 \\
\hline 24 Financial fixed assets & 11.789 .495 & 11.915 .186 & 1.06 & & & & \\
\hline 25 REAL ASSETS & 121.677 .454 & 146.246 .898 & 20.20 & & & & \\
\hline 26 INT ANGIBLE FIXED ASSETS & 0 & 167.308 & $(-----)$ & & & & \\
\hline Total actives & 186.854 .785 & 217.321 .335 & 16.30 & Total passives & 186.854 .785 & 217.321 .335 & 16.30 \\
\hline IX- OFF-BALANCE SHEET & 12.893 .115 & 21.619 .818 & 67.68 & IX- OFF-BALANCE SHEET & 12.893 .115 & 21.619 .818 & 67.69 \\
\hline 90 APPROPRIATION ACCOUNTS & & & & 90 APPROPRIATION ACCOUNTS & & & \\
\hline $\begin{array}{l}\text { 91 NON-CASH COMMITMENT AND } \\
\text { PERSONAL ASSETS }\end{array}$ & 11.620 .194 & 12.024 .843 & 3.48 & $\begin{array}{l}\text { 91 NON-CASH COMMITMENT AND } \\
\text { PERSONAL ASSETS }\end{array}$ & 11.620 .194 & 12.024 .843 & 3.48 \\
\hline $\begin{array}{l}92 \text { COMMITMENT } \\
\text { ACCOUNTING }\end{array}$ & 1.272 .921 & 9.594 .975 & 653.78 & 92 COMMITMENT ACCOUNTING & 1.272 .921 & 9.594 .975 & 653.78 \\
\hline
\end{tabular}

$\%$ Change $=($ current year amount - previous year's amount $) /$ Previous year's amount 


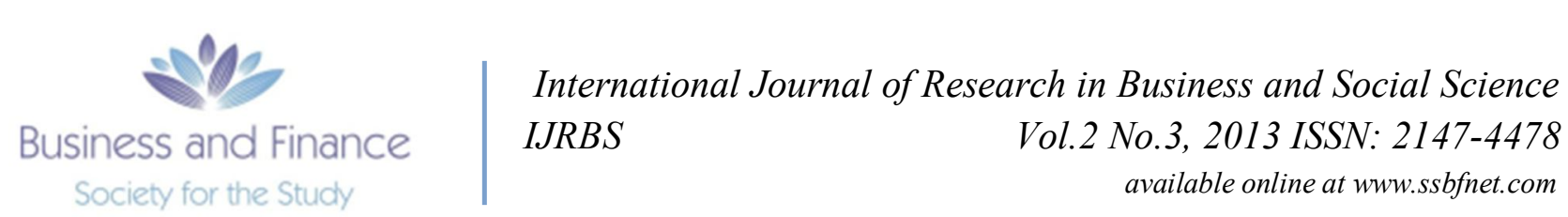

When the outcomes of the horizontal analysis are examined, it is seen that important changes occur in the municipality's financial standing. By transition from 2011 to 2012, it is seen that current assets increased by $\% 12.25$, fixed assets increased by \% 17.77, short term foreign resources increased by \% 29.87 and equities increased by \% 8.63, while long term foreign resources decreased by \% 94.70. It is observed that the increase in current assets is caused by the receivables' items and that there is a $\% 447.40$ increase in the other receivables item within this group. Moreover, a \%24.80 increase in the activity receivables (proceeding based receivables from incomes) and a corresponding \% 60.28 increase in the activity payables show that collectibles could not be collected, payments have been deferred and that the standing of the municipality is deteriorating. The reason for the actual increase in fixed assets however is the \%20.20 increase in tangible assets. While this increase is considered to be normal, it shows that underground and ground investments, which are the main activity field of the municipality, have increased. The fact that the increase in fixed assets is higher than the increase in current assets is considered to be normal for a public institution with high infrastructure activities. The reason for the high increase in the short term foreign resources is the 60.28 increase in activity debts. The \%-94.70 decrease in long term foreign sources can be shown as the reason for the increase in short term foreign sources. When we look at the results of the analysis, it is striking that short term foreign sources are higher that long term foreign sources and that there is a \%-94.70 decrease in long term foreign sources. It is necessary to analyze the reasons for this rapid decrease in long term foreign resources. Despite the \% 10.36 decrease in the previous year's operating results, the $\% 8.63$ increase in equities is caused by $\% 20.74$ increase in the net assets. When we look at the off balance sheet items however, the extraordinary increase of $\% 653.78$ in the commitment accounting must be analyzed.

\subsection{Implementation Of The Analysis According To The Percentage Method In The Municipality Of Beylikdüzü}

By this technique, the ratio of all items in the operating results (income) table or the balance sheet to the whole is determined and these ratios assessed. The total sum of actives and passives for the balance sheet or the receivables and payables sections are taken as one hundred percent; and the ratio of all debts and receivables' accounts to total debts/receivables are calculated. The analysis of the income statement however is made by taking net sales as one hundred percent for private sector companies (Tenker and Akdoğan, 2010, p:302). Since the main activity of public institutions is to provide service rather than yielding sales revenues, income statements prepared for public institutions are prepared to display all incomes and expenditures yet without focusing on sales. Therefore, expenditures are written into the debts section of the incomes and expenditures statement, while incomes are written into the receivables section and the difference between the sums of both sections show the activity profits/losses for the term. In the vertical analysis of such income-expenditure tables, the total sums of incomes and expenditure are considered to be one hundred percent, whereby an analysis may be done by calculating the rates within the sum of the income and expenditure items.

In the study, a vertical analysis is realized on the Operating Results Statements of the municipality of Beylikdüzü for the year 2012 which has been taken as a sample. The revenue and expense numbers in the operating results statements of the municipality of Beylikdüzü are taken as 100, and the percentage of each item in the total is calculated. 
Table 2: Beylikdüzü Municipality Table of Activity Results for Year 2012 Vertical Percentages

\begin{tabular}{|c|c|c|c|c|c|c|c|c|}
\hline \multicolumn{6}{|c|}{ BEYLİKDÜZÜ MUNICIPALITY TABLE OF ACTIVITY } & & & \\
\hline \multirow{2}{*}{$\begin{array}{l}\begin{array}{l}\text { Account } \\
\text { code }\end{array} \\
\text { cols }\end{array}$} & \multicolumn{5}{|c|}{ Auxiliary accounts } & \multirow[b]{2}{*}{ TYPE OF EXPENDITURE } & \multirow[b]{2}{*}{$\begin{array}{c}\text { Current Year } \\
\text { (2012) }\end{array}$} & \multirow[b]{2}{*}{$\begin{array}{c}\text { VERTICAL } \\
\text { ANALYSIS } \\
(\%) \\
\end{array}$} \\
\hline & I & II & III & IV & V & & & \\
\hline 630 & 1 & & & & & ERSONNEL EXPENDITURES & 18.693 .700 & 9.37 \\
\hline 630 & 2 & & & & & $\begin{array}{l}\text { UBLIC PREMIA EXPENDITURES } \\
\text { UADE FOR THE SOCIAL } \\
\text { ECURITY INSTITUTION }\end{array}$ & 3.442 .350 & 1.73 \\
\hline 630 & 3 & & & & & $\begin{array}{l}\text { ROCUREMET } \\
\text { XPENSES FOR GOODS } \\
\text { IND SERVICES }\end{array}$ & 86.297 .400 & 43.25 \\
\hline 630 & 4 & & & & & NTEREST EXPENSES & 4.000 .000 & 2 \\
\hline 630 & 5 & & & & & URRENT TRANSFERS & 5.487 .000 & 2.75 \\
\hline 630 & 6 & & & & & APITAL EXPENSES & 62.618 .600 & 31.38 \\
\hline 630 & 7 & & & & & APITAL TRANSFERS & 1.000 .000 & 0.5 \\
\hline 630 & 9 & & & & & $\begin{array}{l}\text { UPPLEMENTARY } \\
\text { PPROPRIATIONS }\end{array}$ & 18.000 .000 & 9.02 \\
\hline TOTAI & PEI & $\mathbf{D}$ & JRES & & & $\mathbf{1 9 9 . 5 3 8 . 4 5 0}$ & 100 & \\
\hline
\end{tabular}

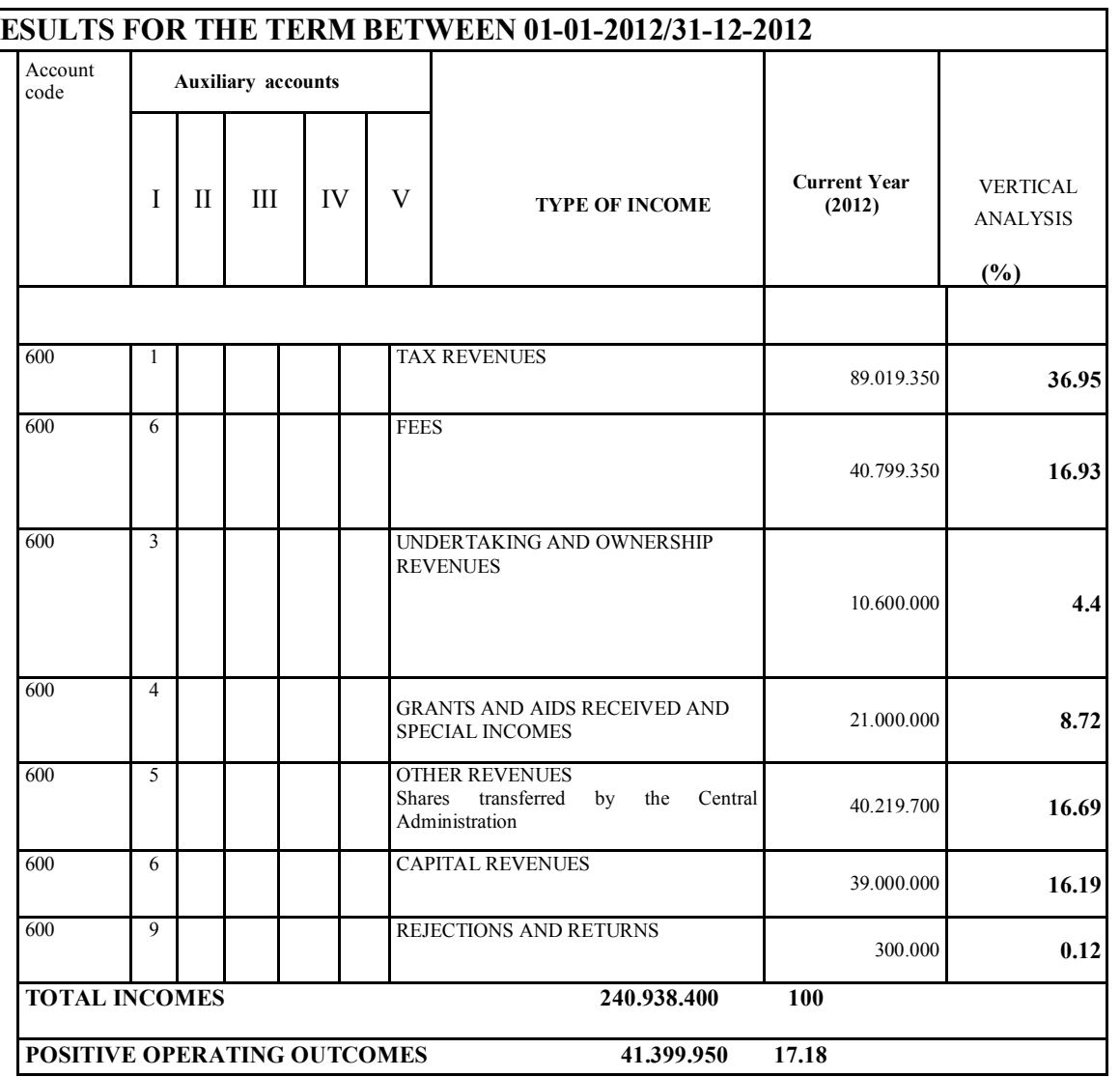


As may be understood from the analysis results present in the table above, $\% 9.37$ of municipality expenses is spent on personnel expenditures, while $\% 43.25$ thereof is spent for the procurement of goods and services. It is possible to say that these expenditures are normal for a municipality and there is nothing striking in the ratios. Although it is observed that $\% 53.88$ of municipality incomes are comprised of shares from tax and duty revenues when municipality revenues are examined the share of tax revenues is \% 39.95. When the items of the financial statement are examined in detail it is understood that these tax revenues are comprised of realty tax, electricity and natural gas consumption taxes and sanitation tax revenues. The fact that tax and duty revenues hold such an important share in total revenues shows that the institution is successful in collecting taxes and fees and that the local community act consciously in fulfilling its responsibilities. Moreover, the fact that the grants and aids received together with the total percentage of other revenues including shares from central revenues amounts to \% 25.41 and the dependency of municipality revenues on overall budget incomes poses a risk for the municipality. Shrinkage in the country's economy and decreases in tax revenues will also significantly affect the revenues of the municipality. In order to decrease this risk, it is considered that the municipality must increase its substantial revenues. The positive operating result for the term however is $\% 17.18$ of the institution's revenue, while it is possible to say that the institution has grown at a rate of $\% 17.18$.

\subsection{Implementation Of The Analysis According To The Ratio Method In The Municipality Of Beylikdüzü}

The ratio analysis is the display of the mathematical relation between items by the appropriation of financial items. In the ratio analysis, items are expressed as the multiples or percentages of one another (Tenker and Akdoğan, 2010, p:374). In the study, the items which have meaningful relationship between themselves in the Balance Sheet and Operating Results Statement of the municipality of Beylikdüzü are rated to each other and the results are interpreted. 
Table 3: Beylikdüzü Municipality Year 2012 Ratios

\begin{tabular}{|c|c|c|}
\hline \multicolumn{3}{|c|}{ BEYLİKDÜZÜ MUNICIPALITY RATIOS FOR YEAR 2012} \\
\hline & RATIOS & $\begin{array}{c}\text { COMMENTS } \\
\end{array}$ \\
\hline $1-$ & $\begin{array}{l}\text { Total Incomes / Total Expenditures } \\
240.938 .400 / 199.538 .450=1.2\end{array}$ & $\begin{array}{l}\text { Incomes yielded by the municipality can cover its expenses } 1.2 \\
\text { times. In addition to covering expenses, the fact that the ratio came } \\
\text { out to be higher than } 1 \text { shows that the operative results of the } \\
\text { institution are positive. }\end{array}$ \\
\hline 2- & $\begin{array}{l}\text { Tax incomes / Total expenses } \\
89.019 .350 / 199.538 .450=0.45\end{array}$ & $\begin{array}{l}\% 45 \text { of total expenses can be covered by the tax revenues collected } \\
\text { by the municipality. Nearly half of expenses can be covered by tax } \\
\text { revenues. This in turn shows the success of municipalities in their } \\
\text { tax practices. }\end{array}$ \\
\hline $3-$ & $\begin{array}{l}\text { Tax incomes / population } \\
89.019 .350 / 218.120=408\end{array}$ & $\begin{array}{l}\text { It is observed that the tax revenue per person as a result of } \\
\text { proportioning the tax revenues to the population is } 408 \mathrm{TL} \text {. }\end{array}$ \\
\hline 4- & $\begin{array}{l}\text { Total incomes / population } \\
240.938 .400 \quad / 218.120=1.105\end{array}$ & $\begin{array}{l}\text { It is observed that the public revenue per person yielded as a result } \\
\text { of proportioning total revenues to the population amounts to } 1.105 \\
\text { TL. This figure shows the success of the institution in obtaining } \\
\text { revenues and that citizens have an awareness of their responsibility. }\end{array}$ \\
\hline $5-$ & $\begin{array}{l}\text { Total expenses / population } \\
199.538 .450 / 218.120=915\end{array}$ & $\begin{array}{l}\text { It is observed that the public expenditure per person yielded by } \\
\text { proportioning total expenses to the population is } 915 \mathrm{TL} \text {. The fact } \\
\text { that the said figure is below the institution's figures for revenues per } \\
\text { person is considered to be a positive situation and shows that the } \\
\text { terms shall be concluded with a positive operative outcome. }\end{array}$ \\
\hline 6- & $\begin{array}{l}\text { Fee revenues / Total expenses } \\
40.799 .350 / 199.538 .450=0.20\end{array}$ & $\begin{array}{l}\% 45 \text { of total expenses can be covered with the duty revenues } \\
\text { collected by the municipality. }\end{array}$ \\
\hline 7- & $\begin{array}{l}\text { Undertaking and property revenues / Total expenses } \\
10.600 .000 / 199.538 .450=0.05\end{array}$ & $\begin{array}{l}\% 5 \text { of total revenues can be covered by the undertaking and } \\
\text { property revenues by the municipality. The lowness of this figure is } \\
\text { striking, and an analysis on the matter is considered to be } \\
\text { appropriate. }\end{array}$ \\
\hline $8-$ & $\begin{array}{l}\text { Grants and aids / Total expenses } \\
21.000 .000 / 199.538 .450=0.10\end{array}$ & $\begin{array}{l}\% 10 \text { of total expenses can be covered by the grants and aids } \\
\text { received by the municipality. }\end{array}$ \\
\hline 9- & $\begin{array}{l}\text { Shares received from the central administration / Total } \\
\text { expenses } \\
40.219 .700 / 199.538 .450=0.20\end{array}$ & $\begin{array}{l}\% 20 \text { of total expenses can be covered with the shares obtained from } \\
\text { the central administration. The highness of this rate, and the } \\
\text { dependence of municipality revenues on overall budget revenues at } \\
\text { such an extent can pose a risk for the municipality. }\end{array}$ \\
\hline $10-$ & $\begin{array}{l}\text { Current assets } / \text { KVYK } \\
55.789 .780 / 118.370 .158=0.47\end{array}$ & $\begin{array}{l}\text { While it is expected that this rate, named as current assets in the } \\
\text { private sector, be } 2 \text {; the institutions current asset rate is } 0.47 \text {. The } \\
\text { figure shows that the institution's current assets cannot cover } \\
\text { KVYK resources and moreover that the institution shall have a } \\
\text { liquidity shortage, face difficulties in paying its debts and that its } \\
\text { credit values will fall. }\end{array}$ \\
\hline $11-$ & $\begin{array}{l}\text { Personnel expenses / Total income } \\
18.693 .700 / 240.938 .400=0.08\end{array}$ & $\begin{array}{l}\text { It is observed that } \% 8 \text { of total revenues is used for personnel } \\
\text { expenses. This ratio is considered to be normal for public } \\
\text { institutions which employ high numbers of staff. }\end{array}$ \\
\hline $12-$ & $\begin{array}{l}\text { Goods and services procurement expenses / Total } \\
\text { incomes } \\
86.297 .400 / 240.938 .400=0.36\end{array}$ & $\begin{array}{l}\text { It is observed that } \% 36 \text { of total revenues are used for the } \\
\text { procurement of goods and services. This ratio is considered to be } \\
\text { normal for a public institution which keeps the purpose of serving } \\
\text { the public in the foreground. }\end{array}$ \\
\hline $13-$ & $\begin{array}{l}\text { Capital expenditures / Total income } \\
62.618 .600 / 240.938 .400=0.26\end{array}$ & $\begin{array}{l}\text { It is observed that } \% 26 \text { of total incomes is used for capital expenses. } \\
\text { This figure shows that the municipality uses approximately } 1 / 4 \text { of its } \\
\text { revenues for underground and superstructure investments and that } \\
\text { the municipality shows a tendency towards investment. }\end{array}$ \\
\hline $14-$ & $\begin{array}{l}\text { Interest expenses } / \text { Total income } \\
4.000 .000 / 240.938 .400=0.02\end{array}$ & $\begin{array}{l}\text { The allocation of merely } \% 2 \text { of the total income for interest } \\
\text { expenses shows that the municipality utilizes he appropriate } \\
\text { resources for debts. Form another viewpoint, the municipality is } \\
\text { able to meet its expenses by equities and abstains from going into } \\
\text { debt. }\end{array}$ \\
\hline
\end{tabular}

It is also possible to use a ratio analysis specific to public institutions in the analysis of the public sector's financial statements. One of the pioneering studies in this area is the Financial Indicators for Local Governments analysis system developed by ICMA (International City Management Association). The said analysis method developed by ICMA aims at the assessment of local administrations' financial standing and provides the opportunity to observe changes occurring in the financial standing in course of time. The ICMA system ensuring a general economic status 
analysis is comprised of 12 factors based on financial table data and socioeconomic indicators and the 36 indicators representing these factors (Groves, Godsey and Shulman, 1981, p:19). After obtaining all indicators, one can have an idea of the financial standing of the local administration/ municipality, thereby assessing the financial standing of the administrator activities' success and the financial state of the local administration and more accurate decisions may be taken for the future by making forecast for the future. The reason why these practices are theoretically present in the study is that the ratios to be calculated for these practices cannot be calculated by predicating on merely financial statement data. Detailed data which are not included in municipalities' financial statements are also needed.

In addition to this analysis system developed by ICMA, entities such as CICA (Canadian Institute of Chartered Accountants) (Indicators of Government Financial Condition, CICA, Report, 1997) and GASB (Government Accounting Standards Board) (An Analyst's Guide to Government Financial Statements, Dean Michael Mead, GASB, 2001) have also made contributions to financial statement analyses and financial standing analysis studies with the reports and guides they have published. In addition to these institutional studies, some academicians have also made contributions to the development of the literature for the analysis of public institutions' financial statements by the analysis methods they have suggested as well as their individual or common studies. An example which may be given for these studies is the " 10 point financial standing test" developed by Ken W. Brown for determining the financial standing of small scale local town administrations. Brown has used 10 financial ratios representing the four financial factors within the system he has developed. Contrary to other analyses, Brown's system aims at comparing many small local administrations and thereby grading these municipalities. For this reason the system is comprised of three stages. During the first stage, financial ratios are calculated for each municipality, while these financial ratios are compared during the second phase. As a result of the comparisons, municipalities having the best financial rates ranking in the first quartile for each ratio were given +2 points, municipalities in the second best quartile were given +1 point, municipalities in the third best quartile were given 0 points, while municipalities falling within the worst quartile were given -1 points. After such grading made for all financial rates, municipalities get the chance to obtain points between +20 and -10 points (Brown, 1993, p: 21-26). At the last phase, these total points received are examined while the financial standing of the municipality as compared to other municipalities is ascertained.

Another study suggesting a ratio which may be yielded by using data of balance sheets and income statements, which are the two basic financial tables produced by the accrual based accounting system for the analysis of local governments' financial statements is "Measurement of the financial state: A study on the United States" published by Xiaohu Wang, Lynda Dennis and Yuan Sen Tu. (Xiaohu, Lynda and Yuan, 2007, p: 1-21). 11 items of financial rates are suggested in the study and the financial state of the local governments is measured from four angles by said ratio. These are the current position, budget adequacy, long term debt solvency and the sustainability of services.

\section{Findings}

Although it is possible to apply the horizontal and vertical analysis from amongst financial analyses used in enterprises in municipalities per se, there are differences in the ratios used in the ratio analysis and the construal of the outcomes thereof. The main reason thereof is the conceptualization and implementation of analysis techniques is that profits are held in foreground in enterprises. The main purpose in the municipalities however is the provision of services. What matters is to ensure that incomes are used in a most efficient manner, while profits do not come that much into the foreground. When you look at matters from this viewpoint the development of financial analysis techniques for the overall balance of incomes and expenditures when making the financial analysis of municipalities and the use of various ratio for understanding their financial standing will also be applicable.

It is impossible to think of municipalities as independent from economic developments. Therefore municipalities cannot be held afar from the cost, performance, quality, customer satisfaction, efficiency and productivity criteria in the private sector. However, carrying the success criteria for the private sector forward to the municipality administration in full is impossible in terms of serving the "public interest". Therefore, when determining the success criteria to be set for municipal administrations; it is vital that the quality of services to be provided, the structure of the public institution and the legal infrastructure be researched. The construal of analyses to be made on financial statements in municipalities is also a matter which must be assessed from different angles. It is impossible to read municipalities' financial statements as in enterprises financial statements, although there are various similarities. The reasons for the matters appearing to be risky must be looked into by the results of the analysis. Strict judgments must be avoided when merely analyzing financial tables. One must not forget that the main duty of municipalities is to provide services to the local community in the region and serve the public interest. 


\section{Conclusions}

One of the fundamental issues that we encountered during the study was that there are not serious sanctions to be imposed for the prevention of mistakes and frauds made on the accounting records. In the private sector, if a company reduces its expenses by way of an erroneous accounting entry, then it is obliged to pay for more taxes. If a reverse situation is detected in a tax audit, then such a company is obliged to pay retrospective taxes, tax punishment, and interest for default. In addition if it is considered to be a guilt, then terms and conditions of the penal code becomes applicable (Türkyener, 2010, p:81) Therefore, there are both monetary and penal sanctions on all the accounting errors and frauds which effect the revenues and expenses, which is a pressure on the implementers for acting more carefully. For public enterprises and organizations similar sanctions should be applicable for the same errors and frauds, and accounting operations should be carried out more seriously.

Another conclusion achieved as a result of the study conducted, is that there are no information on financial statements and activity results on many municipalities' websites. For this reason, people living that region cannot see the procedures undertaken by the people they've voted for and as a result thereof accountability and transparency cannot be accomplished. As stated during the study, this is the reason why ICMA data are not used. Moreover, administrators/managers do not use accounting data in the management of their institutions. Managers, rather than seeing accounting as a mandatory task which must be accomplished by law, must try to consider that it is a function of management and try to take advantage of accounting data. Studies should be carried out in order that the financial statements of all of the public enterprises and organizations can be displayed on the official internet pages of such organizations and enterprises.

As a result, it has been found out that the financial statement analyses utilized by the private sector enterprises can also be used in the financial statements of the public enterprises and organizations based on the applications realized in the municipality of Beylikdüzü by taking into consideration the objectives of these public organizations and enterprises. AS a result of such applications, financial carnet application should be started in the municipalities on the condition that the future sources and services should be taken into consideration. With the implementation of financial carnet both the effectiveness and efficiency of the expenses and the welfare of the people of the country will increase.

\section{Reference}

Alkış Abdulsamet (2011). Yönetim Sorumluluğu Modelinde Hesap Verme Sorumluluğu. Mevzuat Dergisi, http://www.demud.org.tr/asalkis.pdf, (Erişim Tarihi: 12.09.2011).

Başaran İsmail (2008). Kent ve Yerel Yönetim. Okutan Yayınc1lık: Türkiye.

Brown W. Ken (1993). The 10-Point Test of Financial Condition: Toward an Easy-to-Use Assessment Tool for Smaller Cities. Government Finance Review, December, p: 21-26.

Eren Veysel (2009). Kamu Performans Yönetiminde Ölçüt Sorunu: İdari Faaliyetlerde Başarı Ölçütleri. Amme İdaresi Dergisi, Sayı 2, s:3.

Ferlie Ewan et all. (1997). The New Public Management In Action. Oxford University Press.

Groves M. Sanford, Godsey W. Maureen, Shulman A. Martha (1981). Financial Indicators for Local Government, Budgeting and Finance, p:5-19.

Horrigan James O. (1968). A History of Financial Ratio Analysis. The Accounting Review, p.284-294.

İtibar Erdoğan (2007). Kamu Mali Yönetiminde Mali Saydamlık ve 5018 Sayllı Kamu Mali Yönetimi ve Kontrol Kanunu Çerçevesinde Değerlendirilmesi. Bütçe Dünyası, Sayı: 24, Cilt:2, s: 24-31.

Karaarslan Erkan (2004). Ülkemizde Devlet Muhasebesinin Serüveni. Sayıştay Dergisi, Sayı 54, s.37.

Mead Dean Michael (2001). An Analyst's Guide to Government Financial Statements. GASB.

Nadaroğlu Halil (2011). Mahalli İdareler. Beta Yayınları, 7. Baskı: Türkiye

Tenker Nejat, Akdoğan Nalan (2010). Finansal Tablolar Mali Analiz Teknikleri. Gazi Kitabevi: Ankara.

Türkyener Mustafa Can (2010). Kamu Muhasebe Sisteminde Revizyon ve Hedefler. Dışdenetim Dergisi, Sayı 1, s:81. 
Türkyener Mustafa Can (2011). Belediyelerde Mali Raporlama ve Mali Analize İlişkin TemelzSorunlar. Dış Denetim Dergisi, Nisan Mayıs Haziran Sayısı, s:47-58.

Wall Alexandre (1919). Study of Credit Barometrics. Federal Reserve Bulletin, p: 229-243.

Xiaohu Wang, Lynda Dennis, Yuan Sen Tu (2007). Measuring Financial Condition: A Study of U.S. States. Public Budgeting and Finance, p.1-21.

03/07/2005 Ratification Date, Municipalities Law no. 5393, First Section, General Provisions, Article 3

10/12/2003 Ratification Date, Law on Public Administration and Control No. 5018

CICA, Report( 1997) Indicators of Government Financial Condition,

www.beylikduzu.gov.tr/nufus.aspx 